Newsl., 3: 16-18. - Vesmanis I. E, Sans Coma V., Fons R., Vesmanis A. \& Alcover J. A., 1980: Über die Coronar-Höhe des Unterkiefers als trennendes Merkmal (?) verschiedener Wimperspitzmaus-Taxa im Mittelmeerraum (Mammalia, Insectivora). Miscellània Zool., 6: 135-139. - Vesmanis I. E. \& Vesmanis A. 1979a: Bemerkungen zur Rostrum-Länge einiger Wimperspitzmausarten im Mittelmeergebiet (Mammalia, Insectivora, Crocidura). Zool. Abh. Mus. Tierk. Dresden, 36: 93-100. - Vesmanis I. E. \& Vesmanis A., 1979b: Ein Vorschlag zur einheitlichen Altersabstimmung bei Wimperspitzmäusen (Mammalia: Insectivora: Crocidura). Bonn zool. Beitr., 30: 7-13. - Vesmanis I. E. \& Vesmanis A., 1980: Bemerkungen zur Morphometrie des $\mathrm{P}^{4}$ bei einigen Wimperspitzmaus-Arten im Mittelmeerraum (Insectivora: Crocidura), Zool, Beitr. N. F., 26: 9-21. - Vesmanis I. E. \& Vesmanis A., 1981: Zum Vorkommen der Gartenspitzmaus, Crocidura suaveolens (Pallas, 1811), auf der Mittelmeerinsel Capraja (Italien). Zool Abh. Mus. Tierk. Dresden, 38: 83-93 - Witte G., 1964: Systematik der Insektenfresser des Monte Gargano Gebietes (Italin). Bonn. zool. Beitr., 15: 1-35

Accepted, February 12, 1986.

\title{
Fecal Crude Protein Relative to Browsing Intensity by White-Tailed Deer on Wintering Areas in Maine
}

ZAWARTOSC BIAŁKA W KALE JELENIA WIIRGINSKIEGO, ODOCOILEUS VIRGINIANUS A INTENSYWNOSC ZEROWANIA ZIMA W MAINE

Thomas P. HODGMAN ${ }^{1}$ \& R. Terry BOWYER 2

Hodgman T. P. \& Bowyer R. T. 1986: Fecal crude protein relative to browsing intensity by White-tailed deer in wintering areas in Maine. Acta theriol., 31, 26: $347-353$ [With 3 Tables]

The efficacy of using fecal crude protein (FCP) from white-tailed deer (Odocoileus virgianus) to rank the quality of five wintering areas in central Maine, U.S.A. was tested by comparisons with browsing intensity on northern white cedar (Thuja occidentalis). FCP averaged $7.6 \%$ on low quality areas, $8.8 \%$ on areas of moderate quality, and $10.4 \%$ on high quality ranges. Measures of browsing intensity including stem diameter at point of browsing, leader lengths of new growth, and percent of new growth removed did not differ significantly with rankings obtained from FCP. FCP provided a time and cost-efficient method of ranking the nutritional status of free-ranging deer on winter ranges. 04988]

Center of Environmental Sciences, Unity College, Unity, Maine, USA

\section{INTRODUCTION}

Browse surveys of white-tailed deer (Odocoileus virginianus) winter range traditionally have been used to appraise habitat quality (Aldous, 1944; Bramble \& Goddard, 1953; Dickinson, 1978; Hout, 1974; Moore

1 Present address: Department of Forestry and Range Management, Washington State University, Pullman, WA, USA 99164.

2 Present address: Department of Biology, Fisheries and Wildlife and Institute of Arctic Biology, 211 Irving Building, Univ, of Alaska, Fairbanks AK, 99775-1780, USA. 
\& Johnson, 1967; Stiteler \& Shaw, 1966; Theberge, 1978; Wetzel et al. 1975). Subjective measures of range condition, however, are open to criticism (Dasmann, 1948; Martin, 1970), and quantitative methods of assessing the intensity of browsing often are tedious and time-consuming (Aldous, 1944; Crete, 1976; Lyon, 1970; Moore \& Johnson, 1967; Stiteler \& Shaw, 1966; Telfer, 1969).

Fecal nitrogen (FN) recently has been suggested as a means of determining dietary quality for free-ranging ruminants (Kie \& Burton, 1984; Leslie \& Starkey, 1985; Mubanga et al., 1985; Wehause 1980). Whether FN and quantitative measures of browsing provide corresponding indices to the quality of winter forage, however, is uncertain. This study compared fecal crude protein ( $\mathrm{FCP}=\mathrm{FN} \times 6.25)$ with two measures of browsing intensity on 5 white-tailed deer wintering areas in central Maine.

\section{METHODS}

Five deer wintering areas near Unity, Waldo County, Maine, U.S.A. were selected as study sites (Area $\mathrm{A}=44^{\circ} 36^{\prime} \mathrm{N}, 69^{\circ} 23^{\prime} \mathrm{W}$; Area $\mathrm{B}=44^{\circ} 36^{\prime} \mathrm{N}, 69^{\circ} 20^{\prime} \mathrm{W}$; Area $\mathrm{C}=44^{\circ} 37^{\prime} \mathrm{N}, 69^{\circ} 16^{\prime} \mathrm{W}$; Area $\mathrm{D}=44^{\circ} 35^{\prime} \mathrm{N}, 69^{\circ} 17^{\prime} \mathrm{W}$; Area $\mathrm{E}=44^{\circ} 34^{\prime} \mathrm{N}$, $69^{\circ} 20^{\prime} \mathrm{W}$ ). These areas ranged from $76-152 \mathrm{~m}$ in elevation and encompassed from 0.8-3.0 $\mathrm{km}^{2}$. Soils, predominantly silty loams, were similar for the wintering areas. All areas included swamps or riparian zones, and were adjacent to agricultural fields, primarily hay and corn. Study areas were heavily forested with dense coniferous overstories; common trees included balsam fir (Abies balsamea), white pine (Pinus strobus), white spruce (Picea glauca), northern white cedar (Thuja occidentalis), and trembling aspen (Populus tremuloides).

Winters are long and sometimes severe with an average temperature of $-7^{\circ} \mathrm{C}$, falling on occasion to $-35^{\circ} \mathrm{C}$; snowfall averages $250 \mathrm{~cm}$. Winter conditions during 1984-1985 were mild with a prevalent January thaw.

Twenty fresh groups of deer feces were collected along randomly located transects in each of the five wintering areas from early to mid-April, 1985. This period was selected because browse still predominated in the diet of deer, and marked increases in FCP do not occur until May in central Maine (Bowyer, unpubl. data). Fecal groups were stored frozen until they were placed in a $50^{\circ} \mathrm{C}$ drying oven for six days. Three groups that developed fungal growths were discarded; the remaining 97 fecal groups were ground with an all-purpose mill and sifted through a 40 -mesh $(0.425 \mathrm{~mm})$ screen. Subsamples of feces from each group then were subjected to standardized micro-Kjeldahl procedures for determination of crude protein (Horwitz, 1975). Diets high in protein-complexing phenolics may lead to problems in using FCP as an index to diet quality (Mould and Robbins, 1981). Leslie and Starkey (1985), however, suggested that the effects of these substances on FCP may be lessened for cervids feeding on diverse diets. Further, the effects of phenolics on FCP would be similar for the study areas.

Northern white cedar is an important winter forage for deer (Aldous, 1941; Banasiak, 1961; Verme, 1965). Indeed, Mattfeld (1984) reported that northern white cedar provided ideal food and cover for wintering deer in the northeastern 
United States. Because this species was both abundant and heavily utliked on all five study areas, it was selected to index the intensity of deer browsing.

Sampling of cedar followed methods described by Wetzel et al. (1975), except that two randomly located transects, each $175 \mathrm{~m}$ in length, were used to locate deer trails on each of the study areas. Each deer trail encountered was followed for $50 \mathrm{~m}$ in both directions, and all cedars within $0.5 \mathrm{~m}$ of the trail were examined for signs of browsing. A sample of leaders of new growth from 1.2-1.8 m above the ground was clipped from each tree, labeled, and returned to the laboratory for measurement. Sampling leaders within this range of heights assured that browse was within the reach of deer, but above that of snowshoe hare (Lepus americanus) (Hodgman \& Bowyer, 1985).

Diameters of browsed twigs and leader lengths have been used widely to assess browsing (Basile \& Hutchings, 1966; Lyon, 1970; Telfer 1969). We measured minimum diameter at point of browsing (DPB) with vernier calipers to the nearest $0.1 \mathrm{~mm}$; the flatness of cedar stems made other standardized measures of diameter difficult. Leader lengths were measured to the nearest $1.0 \mathrm{~mm}$ from the most proximal new growth on a branch to the apex of the terminal bud for unbrowsed stems, or to the point of browsing for utilized stems; percent of leader removed was calculated from these data. Adequate sample sizes for DPB and lengths of browsed and unbrowsed leaders were determined for each area by stabilizing the means (Kershaw 1964). Statistical analyses were performed using the Mann-Whitney $U$ - test, Kruskal-Wallis one-way analysis of variance, and Friedman two-way analysis of variance (Siegel, 1956).

\section{RESULTS}

Mann-Whitney $U$ - tests indicated that diet quality, as indexed by FCP, did not differ significantly $(p>0.10)$ between wintering areas A $(7.4 \%)$ and $\mathrm{B}(7.9 \%)$, or $\mathrm{C}(8.4 \%)$ and $\mathrm{D}(9.2 \%)$. Thus, these areas were

Table 1

Fecal crude protein (FCP) for white-tailed deer wintering areas in April, 1985, Waldo County, Maine, USA.

\begin{tabular}{lrrrc}
\hline \multirow{2}{*}{ Quality of diet } & \multirow{N}{*}{$\mathrm{N}$} & \multicolumn{3}{c}{$\%$ FCP } \\
\cline { 3 - 5 } & & $\mathrm{X}$ & $\mathrm{SD}$ & Range \\
\hline Low & 39 & 7.6 & 1.4 & $4.2-9.8$ \\
Moderate & 39 & 8.8 & 1.9 & $5.2-12.8$ \\
High & 19 & 10.4 & 2.3 & $5.8-15.1$ \\
All & 97 & 8.6 & 2.1 & $4.2-15.1$ \\
\hline
\end{tabular}

combined and categorized as low quality (areas A and B), moderate quality (areas C and D), and high quality (area E) (Table 1). A Kruskal-Wallis one-way analysis of variance showed a highly significant $(p<0.001)$ difference among these three classes representing the quality of diet on wintering areas for white-tailed deer.

Vegetative characteristics reflecting habitat quality also were com- 
pared with the three categories of wintering areas delineated by ECP. A Kruskal-Wallis one-way analysis of variance indicated DPB for northern white cedar increased significantly $(p<0.02)$ as forage quality on wintering areas declined (Table 2). Further, length of unbrowsed leaders increased significantly $(p<0.001)$. with increasing quality of habitat (Table 3). A significant difference $(p<0.05)$ also occurred among areas for the length of leaders browsed by white-tailed deer; however, remaining leader length was less on moderate than low-quality areas (Table 3).

Table 2

\begin{tabular}{|c|c|c|c|c|}
\hline Quality of diet a & $\mathrm{N}$ & $\mathrm{x}$ & $\mathrm{SD}$ & Range \\
\hline Lo & 325 & 1.4 & 0.5 & $0.5-3.8$ \\
\hline Moderate & 235 & 1.3 & 0.5 & $0.5-4.0$ \\
\hline High & 105 & 1.2 & 0.4 & $0.3-2.0$ \\
\hline All & 665 & 1.3 & 0.5 & $0.3-4.0$ \\
\hline
\end{tabular}

a Based on FCP.

Table 3

Leader lengths $(\mathrm{mm})$ of browsed and unbrowsed new growth for northern white cedar on white-tailed deer wintering areas in April 1985, Waldo County, Maine, USA.

\begin{tabular}{|c|c|c|c|c|c|c|c|c|c|}
\hline \multirow{2}{*}{$\begin{array}{l}\text { Quality of } \\
\text { diet a }\end{array}$} & \multicolumn{4}{|c|}{ Unbrowsed leaders } & \multicolumn{4}{|c|}{ Browsed leaders } & \multirow{2}{*}{$\begin{array}{l}\% \text { leader } \\
\text { removed }\end{array}$} \\
\hline & $\bar{N}$ & $\mathrm{X}$ & SD & Range & $\bar{N}$ & $\mathrm{X}$ & SD & Range & \\
\hline Lor & 342 & 67.2 & 20.0 & $20-129$ & 298 & 4.3 & 9.6 & 0 & 93.6 \\
\hline Moderate & 330 & 72.9 & 24.3 & $16-151$ & 472 & 3.4 & 8.7 & $0-76$ & 95.3 \\
\hline High & 124 & 82.6 & 24.3 & $9-172$ & 130 & 10.7 & 13.3 & $0-66$ & 87.1 \\
\hline All & 796 & 72.0 & 23.1 & $9-172$ & 900 & 4.7 & 10.1 & $0-92$ & 93.5 \\
\hline
\end{tabular}

a Based on FCP.

The utility of FCP as an index to the quality of deer habitat was tested by comparing how it ranked wintering areas with rankings obtained using measures of the intensity with which deer foraged on northern white cedar. A Friedman two-way analysis of variance showed no significant $(p>0.30)$ difference in rankings of wintering areas among FCP, DPB, and percent of leader removed. 


\section{DISCUSSION}

A significant difference in $\mathrm{FCP}$ among three classes of wintering areas suggests deer ingested forages of differential quality. Differences in the quality of forages consumed are known to vary with deer density (Kie et al., 1980). High deer density relative to the carrying capacity of the habitat can reduce the quality of foods eaten because of intense intraspecific competition for limited forages (McCullough, 1979). It is unlikely that differences in FCP among areas resulted from variation in the quality of soils. Soils were similar on all areas, and McCullough (1979) has documented that white-tailed deer populations can increase rapidly even in areas with poor soils.

Reliable estimates of browsing intensity have been obtained by measuring DPB (Crete \& Bedard, 1975; Crete, 1976; Lyon, 1970; Peek et al., 1971). Wetzel et al. (1975) reported diameters of browsed stems were greatest in areas of most intense foraging. Bailey (1967) noted decreasing crude protein values with increasing distance from the apex of twigs. Our data show a significant increase in DPB for those areas with the lowest FCP eoncentrations.

The lengths of unbrowsed leaders were significantly longer in the areas of highest forage quality. Unbrowsed leaders of new growth may have grown from stems browsed in previous years, giving new growth a "hedged" appearance typical of overbrowsed ranges. A significant difference also occurred among the lengths of browsed leaders for the areas, although the shortest browsed leaders occurred in the area of moderate forage quality.

Our results support the claim that $\mathrm{FN}$ or $\mathrm{FCP}$ can be a useful index to dietary quality (Arman et al., 1975; Kie \& Burton, 1984; Leslie \& Starkey, 1985; Mubanga et al., 1985; Renecker \& Hudson, 1985; Wehausen 1980); rankings of wintering area quality by FCP, DPB and percent removal of cedar leaders did not differ significantly.

The occurrence of low FCP in areas of highest population density is likely; this relationship for ruminal crude protein was documented by Kie et al. (1980). Other indirect evidence suggests FCP may be a reliable indicator of population size relative to carrying capacity. Fecal groups $(\mathrm{N}=21)$ collected on area $\mathrm{A}$ in April 1983 following a mild winter (similar to that of 1985) averaged 13\% FCP (Bowyer, unpubl. data); this value differed significantly $(p<0.001)$ from $7.4 \%$ FCP in April 1985. This difference in FCP may have resulted from a change in hunting regulations that substantially lowered the kill and increased deer population density.

FCP provides a less time-consuming and more cost effective method than browse surveys for ranking the nutritional status of ruminants 
on different wintering areas. We conclude FCP is a valuable tool for managing free-ranging populations of wild ruminants.

Acknowledgements: Funding for this project was provided, in part, by the Penobscot County Conservation Association. We gratefully acknowledge L. Hall for help with sampling and M. Duni for information concerning the study areas.

\section{REFERENCES}

Aldous S. E., 1941: Deer management suggestions for northern white cedar types. J Wildl. Manage., 5: 9C-94. - Aldous S. E., 1944: A deer browse survey method. J. Mammal., 25: 130-136. - Arman P., Hopcraft O. \& McDonald I., 1975: Nutritional studies on East African herbivores: 2. Losses of nitrogen in faeces. Brit. J. Nutr., 3. 3: 265-276. - Bailey J. A., 1967: Sampling deer browse for crude protein. J. Wildl. Manage., 31: 437-442. - Banasiak C. F, 1961: Deer in Maine. Maine Dept. Inland Fish. Game, Game Bull., 6: 1-159. - Basile J. V., \& Hutchings S. S., 1966: Twig diameter-length-weight relations of bitterbrush. J. Range. Manage., 19: 34-38. - Bramble W. C. \& Goddard M. K., 1953: Seasonal browsing of woody plants by white-tailed deer in the ridge and valley section of eentral Pennsylvania. J. For., 51: 815-819. - Crete M. \& Bedard J., 1975: Daily browse consumption by moose in the Gaspe' Peninsula, Quebec. J. Wildi. Manage., 39: 368-373. - Crete M., 1976: Estimation of winter mortality of deer in Quebec. Can. Field-Nat., 90: 397-403. - Dickinson N., 1978: Evidence of browsing as a guide to mapping deer winter range. N. Y. Fish Game J., 25: 170-174. - Dasmann W. P., 1948: A critical review of range survey methods and their application to deer management. Calif. Fish Game, 34: 189-207. Hodgman T. P. \& Bowyer R. T., 1985: Winter use of arboreal lichens, Ascomycetes, by white-tailed deer, Odocoileus virginianus, in Maine. Can. Field-Nat. 99: 313-316. - Hunt J., 1974: Winter habitat of white-tailed deer at Thirty-one Mile Lake, Quebec. Can. Field-Nat., 88: 293-301. - Horwitz W, 1975: Official methods of analysis of the association of official analytical chemists. 12th Edition. $1094 \mathrm{pp}$. - Kershaw K. A., 1964: Quantitative and dynamic ecology. Edward Arnold, London. 183 pp. - Kie J. G. \& Burton T. S., 1984: Dietary quality, fecal nitrogen and 2,6 diaminopimelic acid in black-tailed deer in northern California. U.S.D.A. For. Sery. Pac. Southwest Res. Exp. Sta., Res. Note PSW-364. 3 pp. - Kie J. G., Drawe D. L. \& Scott G., 1980: Changes in diet and nutrition with increased herd size in Texas white-tailed deer. J. Range Manage., 33: 28-34. - Leslie D. M. Jr. \& Starkey E. S., 1985: Fecal indices to dietary quality of cervids in old-growth forests. J. Wildl. Manage., 49: 142-146. - Lyon L. J., 1970: Length-and weight- diameter relations of serviceberry twigs. J. Wildl. Mange., 34: 456-460. McCullough D. R. 1979: The George Reserve deer herd: population ecology of a K-selected species. Univ. Michigan Press, Ann Arbor. 271 pp. - Martin S. C., 1970: Determining animal consumption. [In: "Range and wildlife habitat evaluation - a research symposium"| U.S.D.A. For. Serv. Misc. Publ., 1147: 93-100. Mattfeid G. F. 1984: Northeastern hardwood and spruce/fir forests. [In: "White-tailed deer ecology and management" McCabe R. E. \& Jahn L. R., eds.] Stackpole, Harrisburg, Pa.: 30₹-330. - Moore W. H. \& Johnson F. M., 1967: Nature of deer browsing on hardwood seedlings and sprouts. J. Wildl. Manage., 31: 351-353. Nould E. D. \& Robbins C. T., 1981: Nitrogen metabolism in elk. J. Wildl. Manage., 45: 323-334. - Mubanga G., Holechek J. L., Valdez R. \& Schemnitz S. D., 1985: Relationships between diet and fecal nutritive quality in mule deer. Southwest. Nat., 30: 573-578. - Peek J. M., Krefting L. W. \& Tappeiner J. C., 1971: Variation in twig diameter weight relationships in northern Minnesota. J. Wildl. Manage., 35: 501-507. - Renecker L. A. \& Hudson R. J., 1985: Estimation of dry matter intake of free-ranging moose. J. Wildl. Manage., 49: 785-792. - Stiteler W. M., Jr. \& Shaw S. P., 1966: Use of woody browse by white-tailed deer in heavily forested areas of northeastern United States. Trans. N. Am. Wildl. Nat. Res, Conf., 31: 205-212 - Siegel S. 1956: Nonparametric statistics for the behavioral sciences. McGraw-Hill, New York. 312 pp. - Telfer E. S., 1969: Twig weight-diameter relationships for browse species. J. Wildl. Manage., 33: 917-921. - Theberge J. B., 1978: Evaluation of the winter range of white-tailed deer in the Point Pelee 
National Park, Ontario. Can. Field-Nat., 92: 19-23. - Verme L. J., 1965: Swamp conifer deer yards in northern Michigan. J. For., 63: 523-529. - Wehausen J. D., 1980: Sierra Nevada highorn sheep: history and population ecology. Unpubl. Ph. D. dissert., Univ. Michigan, Ann Arbor. 240 pp. - Wetzel J. F., Wambaugh J. M. \& Peek, J. M., 1975: Appraisal of white-tailed deer winter habitats in northeastern Minnesota J. Wildl. Manage., 39: 59-66.

Accepted, April 14, 1986.

\title{
A Method for Determining Optimum Distance Between Traps on Line Transects
}

METODA OKRESLANIA OPTYMALNEJ ODLEGLOSCI MIEDZY PULAPKAMI W LINII

\author{
S. E. BRAUN HILL \& Daniel F. WILLIAMS
}

Braun Hill S. E. \& Williams D. F., 1986: A method for determining optimum distance between traps on line transects. Acta theriol., 31, 26: $3 \bar{s} 3-358$.

Line transects are often the choice of trap layout for studies of species composition and relative abundance within communities of small mammals. We present a method for determining the optimum distance between traps on lines that will yield a uniform sampling area for each trap and thus maximize catch per effort. The method relies on finding the minimum intertrap distance at which captures are equal in both inner and end traps of short lines. We tested the method in two conifer forest communities of the Sierra Nevada of California. Ten 4-trap lines each of $10-\mathrm{m}, 15-\mathrm{m}$, and $20-\mathrm{m}$ spacing were deplnyed. The optimum intertrap distarce in these communities was $15 \mathrm{~m}$. The method described can be used to determine the optimum distance between traps for other types of studies in other communities.

[Dept. of Ecology and Behavioral Biology, University of Minnesota, Minneapolis, Minnesota 55455 USA; \& Dept. of Biological Sciences, California State University, Stanislaus, Turlock, California 95380 USA]

There is a continuing need for reliable estimates of the diversity and relative abundance of small mammals in various plant communities. This need is most apparent in studies to determine the effects of management practices and to estimate the effects of proposed environmental modifications. Problems arise when designing experiments, to collect the needed data. Chief among these is the method of sampling. Trapping is often the only practical method for determining relative abundance and population structure of most species of small mammals. The type of trap and bait used, the configuration of traps in space, the distance between traps, and the timing and duration of trapping all affect the numbers and kinds of mammals caught. The best trapping design is one that will yield the most accurate information with the least expenditure of time and effort.

Several studies on the relative effectiveness of different traps have 12 - Acta theriologica 